\title{
Surveillance, Normalisation, and Repression
}

Version originale française également disponible

Gilles Dorronsoro, Olivier Grojean and Jeanne Hersant

Translator. Adrian Morfee

\section{OpenEdition}

\section{Journals}

Electronic version

URL: http://journals.openedition.org/ejts/4928

DOI: $10.4000 /$ ejts.4928

ISSN: $1773-0546$

Publisher

EJTS

\section{Electronic reference}

Gilles Dorronsoro, Olivier Grojean and Jeanne Hersant, « Surveillance, Normalisation, and Repression

», European Journal of Turkish Studies [Online], Complete List, Online since 23 July 2014, connection on

19 February 2020. URL : http://journals.openedition.org/ejts/4928 ; DOI : 10.4000/ejts.4928

This text was automatically generated on 19 February 2020

(c) Some rights reserved / Creative Commons license 


\title{
Surveillance, Normalisation, and Repression
}

\author{
Version originale française également disponible \\ Gilles Dorronsoro, Olivier Grojean and Jeanne Hersant \\ Translation : Adrian Morfee
}

\section{EDITOR'S NOTE}

Originally published as 'Surveiller, normaliser, réprimer', European Journal of Turkish Studies 8 (2008).

URL: http://ejts.revues.org/3112

1 One of the most fertile developments in contemporary thought has been to place the production of individuals at the heart of its enquiries, thus breaking with philosophical currents positing an a-historical individual. The aim of this special issue ${ }^{1}$ is to enquire into how exactly this process transpires within organisations that normalise, repress, and conduct surveillance of individuals who are either part of an institution or else the object of their operations. The work carried out by institutions using techniques 'relating to the surveillance, diagnosis, and possible transformation of individuals' (Foucault 2004: 7) studied here is intended to halt or prevent deviant behaviour, in the sense used by Howard Becker for whom 'deviance is not a quality of the act the person commits but rather a consequence of the application by others of rules and sanctions to an "offender" (Becker 1963: 9; italics in the original).

2 The diverse nature of the institutions analysed here (the army, the police, a political organisation, and a consulate), all within a 'Turkish context', ${ }^{2}$ is heuristic insofar as it is thus possible to compare different levels of coercion and test more general hypotheses relating to the similarity of practices and their transfer between institutions. Some are institutions of the sovereign State (the police, the army, and a consulate), whilst others are illegal (the PKK); some are open and exert weak coercive power (the consulate) whilst others are total (the army and PKK), that is to say 'cut off from wider society for 
an appreciable period of time' and formally regulating the reclusive modes of living of those who have joined them (Goffman 1961: xiii). The studies presented here are not monographs, and concentrate on an instrument (torture), on the socialisation of agents in an institution (the army, the police, and the PKK), and on controlling a public (a Consul General, and the police once again).

Whilst Foucault's work clearly represents a major step forward, we have avoided privileging discourse over other practices as has sometimes occurred, to the detriment of an analysis of the concrete mechanisms seeking to transform individuals. Discourse does not act as some explanatory dimension on the basis of which the practices of an institution can be given meaning. Similar rhetoric - for instance about the oneness of the Turkish people within and outside the country's borders - can give rise to very different mechanisms depending upon whether it is within the framework of military service in Turkey or a consular post in Greece. Equally, the existence of different discourse and doctrines does not prevent there being similarities in disciplinary measures, however paradoxical this might appear on first sight (the army, the PKK).

This decision to focus on non-discursive dimensions runs up against the capacity of institutions to limit observation and create a particular form of opacity. No doubt the reader will notice the particular difficulties of studying an illegal party such as the PKK, the police, those called up for their military service, or instruments such as torture. Even obtaining authorisation to carry out interviews in security institutions is problematic, to say the least, and direct observation is impossible other than in exceptional cases. Survey work is thus based on indirect sources, and often on prolonged contact with privileged witnesses and informants. This way of conducting research is not always that advocated by sociology textbooks, and methodological purists will be in a position to criticise the results, as they are not based on a series of semi-directive interviews of a representative sample of people. Without wishing to go too far in the opposite direction, the biases of the 'standard' method strike us as in many respects worse than those arising from less formal exchanges carried out over several years.

5 Furthermore, it would be difficult to use autobiography here, an essential source for considering the modifications undergone by an individual due to his passage via an institution. Whilst autobiography does make it possible to take biographic ruptures into account, there are at least two reasons why it is particularly tricky to use here. Autobiography, as a permanent process of constructing the self, is a technique also used by institutions (especially total institutions) to bring about the conversion of individuals. Thus for instance the institution itself (for example the PKK) sometimes demands of individuals that they rewrite their life story. Furthermore, traumatic experiences - such as military service when it leads to young conscripts being sent to the Commandos fighting the PKK, or to the extreme case of torture - lead to a particularly extensive interpretative process obliging the individual to rethink his or her trajectory, in other words to select and interpret salient biographical facts (Kaufmann 2004: 154). From this point of view discourse is primarily a tool for analysing these interpretative processes, and often of limited use in informing researchers about the how institutional mechanisms really function. 


\section{The concept of the institution}

6 For the purposes of the perspective adopted here, what is an institution? Our preoccupations join in part those of François Dubet and what he calls the 'institutional programme': 'there is an institutional programme when values and principles directly lead to a specific professional activity [...] seeking to produce a socialised individual and an autonomous subject' (Dubet 2002: 24). But the idea here is not to restrict analysis to 'professional work on others' (Dubet 2002: 25), and in particular not to think of institutional work as a linear ideal type necessarily resulting in the production of a subject in Touraine's meaning of the term (Touraine 1997).

7 Our analysis is instead based on the operational and programmatic definition put forward by Jacques Lagroye (2002: 116-117): the institution is thus taken as an 'objectified body of rules, balances of power, knowledge and skills, which moreover adhere in places and rites partially inherited from the past, and thus bound by logics over which the individual has all the less control as they are subject to an unceasing process of legitimisation, yet without this institution having any concrete existence other than in the multiplicity of practices carried out by those who thereby bring it into existence'. ${ }^{3}$ This definition nevertheless leads to two series of partially related questions.

On the one hand it insists primarily on the members and representatives of the institutions, having nothing to say about their users or target populations. Yet whilst 'institutions are the products of the practices of their agents' (Lagroye 2002: 115), they are also influenced by their interactions with their public or targets, who can very often be subjected to the same processes of socialisation, surveillance, and control, even though the intensity of these processes obviously varies depending upon the amount of contact with the institution. On the other hand, positing that an institution has no concrete existence outside the practices of the individuals giving it existence should not lead us to conclude that it is always independent of some political project, be this part of the 'field of power of the State' or not (Dezalay \& Garth 1998), seeking to act as a framework for the behaviour of the institution's members, users, and target publics.

9 Our analysis is based on several questions. Do institutions necessarily socialise individuals within normalised roles? Which mechanisms can they use to transform the habitus of their integrated individuals? Are these mechanisms consistent from one institution to the next, and can they tell us something about some larger political project?

\section{Institutions, normalisation, and institutional roles}

10 The results of the studies presented here lead us in the first place to nuance the idea that the institutions always develop a consistent institutional programme, and especially that they necessarily seek to normalise individuals. On the contrary, our surveys of agents and target populations show on the one hand that imposing norms on the institution's agents is a complex and reversible process and, on the other hand, that the institutions' target populations can be subject to contradictory socialisation processes, and even undergo an attempt to deregulate their behaviour. 
11 As Noémi Lévy shows, the creation of a modern police force at the end of the Ottoman Empire entailed imposing a new role - the role of policeman - involving the neutralisation or distancing from ethnic and religious identities. What is more, the policeman needed to free himself from the culture he shared with local 'caids', a culture based on honouring the hierarchy but also one of violence and frequenting places of ill repute. The institutionalisation of the police as the guarantors of public order thus took a relatively long period of time. Benjamin Gourisse's paper describes the opposite process of the deinstitutionalisation of the Turkish police in the 1970s. In a context verging on civil war, and in the absence of a professional ethics that the institution was now unable to promote, the norms were produced outside the institution, primarily in struggles between political actors. This process is only validated by the agents if 'the concrete operating conditions of the police institution inherently contain the conditions for the "dishabituation" (Berger \& Luckmann, 1966) of its participants'.

Furthermore, a specific configuration studied by Jeanne Hersant makes it possible to tackle the question of socialisation from a different angle, that of the regulated competition between institutions in the case of the co-management of the 'Turkish' populations of Thrace by the Turkish and Greek authorities. The individuals find themselves here within overlapping systems of control which are potentially in conflict with another and which produce a field of co-governementality, resulting in the production of a plural habitus where the individual is 'committed to heterogenous and sometimes even contradictory socialisation principles' (Lahire 1998: 35). ${ }^{4}$

Lastly Gilles Dorronsoro, in a paper about a particular form of torture, questions the very idea that the goal for which institutions strive is necessarily the normalisation of individuals. Torture produces an intractable body, including for the tortured person. What is more, far from being a phenomenon affecting only the marginal, torture is sometimes practised against individuals involved in collective actions and endowed with significant social capital acquired via (or prior to) their contribution to the mobilisation. It does not correspond to the scenario of the normalisation of marginal classes typically found in the sociological literature, suggesting instead an institutional strategy to demobilise politically 'dangerous' individuals.

\section{Mechanisms, socialisation, and transformations of the habitus}

14 The institutions studied here are the locus of a secondary socialisation, which leaves the question of the transformation of the habitus by 'continual and hierarchical surveillance systems' (Foucault 2001: 392). If the habitus is an open system of dispositions, which can be transformed by experience, how can the institution draw on practical knowledge to transform the habitus? The internalisation of institutional 'subworlds' here involves various types of surveillance and coercion mechanisms - 'a topdown network of relations, but also to a certain extent a bottom-up and side-to-side one too' (Foucault 2001: 208).

What forms do these mechanisms take? Is it possible to assess their effects? Do they also sometimes operate along identical lines? The division of space carried out by certain institutions raises the question of their ability to actually impose the political 
order they support: contrary to a widespread vision of organisations with clearly marked frontiers, institutions seeking to exercise surveillance are often characterised by their porosity. But other institutions are more concerned with transforming individuals via disciplinary and coercive measures, especially based on traumas so as to lastingly transform individuals, suggesting that it might be possible to identify certain 'families' of measures and mechanisms. And then finally there is the question of the effectiveness of such mechanisms, which always leave individuals some room for manoeuvre, even within total institutions (Goffman 1968).

The contributions by Jeanne Hersant and Noémi Lévy both start by seeking to describe the geographical and social division of space carried out via surveillance mechanisms. The modes of control described are specific to a given territory and are more concerned with surveillance than coercion, be it of the urban population of Istanbul in the late nineteenth century, or the 'Muslim minority' of Western Thrace after the 1974 Cyprus crisis. ${ }^{5}$ Noémi Lévy demonstrates that control measures relate either to space or to the control of populations considered to be dangerous, such as beggars or certain minorities. The division of the urban space of the Ottoman capital was based on police stations [karakol] as well as on controlling risk places such as the coffeehouses. This division of space meant the police became an 'element familiarising [urban] populations with the presence of the State'. Equally, for Jeanne Hersant, 'the surveillance of the Muslim population by Greek and Turkish State institutions set up in Western Thrace [by Greek and Turkish diplomats] was real, but was no longer based on coercive measures".

The papers presented here try to counter a rather simple vision of the institution as a sharply delineated and autonomous entity somehow standing apart from the rest of society. Original configurations have been studied which encourage us to conceive of how control can be exercised on the margins, with positions and functions that operate on the limit of the conventional attributions of institutions. Surveillance in late nineteenth-century Istanbul was also carried out by district wardens [bekçi] and corporations controlling markets, neither of which formed part of the police. In Western Thrace the division of space involved the remuneration of intermediaries within the population under surveillance, as well as practices targeting notables (the provision of resources, courtesy visits) the aim of which, at least today, is more a matter of unifying collective representations than of transforming individuals.

18 The total institutions such as the army and the PKK described by Olivier Grojean and Sümbül Kaya clearly seek on the other hand to modify the habitus of the individuals who have joined them, and the mechanisms they employ are to a certain extent comparable: top-down control is supplemented by peer control, and the control of time via the daily regime is a central mechanism in both instances. 'Compliance', 'mortification techniques', the 'dispossession of the role of the individual' by isolated confinement, conditioning via admission ceremonies, physical contamination, depersonalisation, and loss of autonomy also occur in both. With regard to the PKK, the mechanisms can even extend across the various branches of the institution, and this despite very different contexts (in Syria and Europe for example) - a sign of the ability of the party to control its environment and, especially, to act autonomously of it.

When an institution takes total control of an individual it becomes possible to apply a trauma in a controlled manner, and this becomes a technology for transforming the individual. In total institutions ordeals are part of a rite of passage, and the processes 
used with conscripts and described by Sümbül Kaya provide an example of the ambivalence individuals feel towards these moments of rupture. In the case of torture analysed by Gilles Dorronsoro, control over the individual for a short period of time nevertheless seeks to bring about a profound transformation in them, but without their learning any new role. This case focuses our attention on particular forms of institutional rationality: on one hand the extent to which individuals are taken care of are limited and so therefore are the costs; on the other hand mobilisations are controlled in advance and in a relatively discreet manner.

But what effect do these mechanisms have? Looking for the differences produced from one individual to the next makes it possible to understand the interaction between individuals and institutions (Camilleri 1997). Studies by historians (Loriga 1991) have emphasised the existence of 'institutional slackening', as well as showing that the ability to use these moments of autonomy often depends on the individual's initial dispositions and resources (be they cultural, financial, or symbolical). Hence the discourse of tortured individuals shows that the meaning given to the ordeal differs depending upon the individual's political capital. Equally, adherence to the values of the total institution (the army, the PKK) also seems to depend in part on initial resources. Finally, in the case of the police, Benjamin Gourisse shows how the ethnic identity and politicisation prior to assuming a role can have a very large effect on trajectories within the organisation. However attractive the 'dispositional' hypothesis may be, it should not lead us to overlook the fact that accepting discipline, submission, and attachment to an institution are processes which evolve (and are hence reversible), and often depend upon situational logics and contingent phenomena. A break in the temporality of the activities regulated by the institution can, for example, lead to a questioning of the instituted roles, and even cause individuals to distance themselves from an institution when there is to create a disjunction between their and its expectations, as Olivier Grojean shows for the trajectories of certain PKK activists.

\section{Transversal dimensions}

21 The production of citizen-soldiers within the Turkish national space or of a New Man in the PKK, the practice of torture in the name of protecting the State, and the role of the policeman and consul, are also linked to 'a set of shared beliefs, embedded in institutions, that are bound up in actions and thereby anchored in reality' (Boltanski \& Chiappello 1999: 35). The political nature of these institutions raises several questions: are the projects and mechanisms specific to a given situation? Do models of the mechanisms to be used circulate between State institutions or not? Does a shared universe of meaning endow these institutions with homogeneity?

The first transversal dimension which emerges from our studies is that at certain moments there is a shared ideological universe within the network of institutions making up the State. This universe ensures the requisite cohesion of organisations, making it easier for individuals to move from one to the other, and this independently of the specific measures of each institution. Hence the 'obligatory consensus' - the 'set of judgements and forms of public behaviour required of citizens' in Turkey (Copeaux 2000: 89) - informs the norms which conform to Kemalist ideology. The military institution uses discipline to reinforce the anchoring and structuring of the national habitus in the personality of conscripts. To quote Elias, the 'traits of national group 
identity - what we call the "national character" - are a layer of the social habitus built very deeply and firmly into the personality structure of the individual' (Elias 1991: 209).

The way State institutions conform to one another is far from being automatic, and is an ongoing process that never achieves some form of definitive success. These studies therefore lead us to emphasise on the contrary how great the distance is between institutions. Phases of deinstitutionalisation are often sector-specific (affecting the police but not the Army for example), which is one explanation for the political dynamics that were operative in the 1970s. One of the keys to the presence of " contradictory individual socialisations' is attendance at different institutions with potentially contradictory messages (the university and army for example). What is more, this universe of references is also reproduced outside State institutions, something that ties in with the conclusions of an earlier study of mobilisations (Dorronsoro 2005). Hamit Bozarslan (2001) has also convincingly demonstrated how Kurdish nationalism can, at least at certain periods, adopt the key features of Turkish nationalism.

A second point to retain is the circulation of mechanisms between institutions of the same type. This circulation takes place independently of cultural specificities, on the basis of similitude in the structure of organisations. Hence Noémi Lévy underlines how the process of reorganising the forces of law and order at the end of the Ottoman Empire was largely similar to the changes being experienced by other powers of the period, such as Britain. The adoption of State techniques by institutions such as political parties shows that the circulation of institutional techniques is not limited to the network of State institutions but is based on broader similitude between structures. Total institutions use largely similar techniques (armies and illegal Leninist parties within their ranks) and their practices may literally be built up 'as a mirror image' (Grojean 2005). Finally, the international use of torture is as widespread as is its denunciation.

These two dimensions - the building of a trans-institutional universe of reference and the transfer of institutional technologies - are fundamentally heterogeneous. It is therefore possible to emphasise the disassociation between discourse and practice (or ideology and mechanisms), at least at the level of several institutions, whilst at the same time underlining how institutions work constantly to build a homogenous universe of meaning, thus facilitating the passage of individuals from one institution to another.

\section{BIBLIOGRAPHY}

Amiraux, Valérie (2001) Acteurs de l'islam entre Allemagne et Turquie : parcours militants et expériences religieuses, Paris, L'Harmattan.

Becker, Howard (1963) Outsiders. Studies in Sociology of Deviance, New York, Free Press of Glencoe. 
Berger, Peter; Luckmann, Thomas (1966) The Social Construction of Reality, New York, Anchor Books.

Boltanski, Luc; Chiapello, Eve (1999) Le nouvel esprit du capitalisme, Paris, Gallimard.

Bourdieu, Pierre (1980) Le sens pratique, Paris, Minuit.

Bourdieu, Pierre (1982) 'Les rites d'institution', in Ce que parler veut dire, l'économie des échanges linguistiques, Paris, Fayard, pp. 121-134.

Bozarslan, Hamit (2001) 'Quelques remarques sur le discours historiographique kurde en Turquie : 1919-1980', Asien Afrika Lateinamerika, vol. 49, pp. 47-71.

Camilleri, Carmel (ed.) (1997) Stratégies identitaires, Paris, PUF.

Copeaux, Etienne (2000) ‘Le consensus obligatoire', in Rigoni, Isabelle (ed.) Turquie : les mille visages, Paris, Syllepse, pp. 89-104.

Dezalay, Yves; Garth, Bryant G. (1998) ‘Droits de l'Homme et philanthropie hégémonique’, Actes de la Recherche en Sciences Sociales, 121-122, pp. 23-41.

Dorronsoro, Gilles (ed.) (2005) La Turquie conteste. Mobilisations sociales et régime sécuritaire, Paris, CNRS Editions.

Dubar, Claude (2000) La socialisation. Construction des identités individuelles et collectives, Paris, Armand Colin.

Dubar, Claude; Tripier Pierre (2005) Sociologie des professions, Paris, Armand Colin.

Dubet, François (2002) Le déclin de l'institution, Paris, Seuil.

Elias, N. (1991) The Society of Individuals, London, Continuum

Fliche, Benoit (2007) Odyssées turques. Les migrations d'un village anatolien, Paris, CNRS Editions.

Foucault, Michel (1969) L'archéologie du savoir, Paris, Gallimard.

Foucault, Michel (1975) Surveiller et punir, Paris, Gallimard.

Foucault, Michel (1997) Il faut défendre la société, Cours au Collège de France, 1976, Paris, Seuil/ Gallimard.

Foucault, Michel (2001) Dits et écrits II, 1976-88, Paris, Gallimard.

Foucault, Michel (2004) Sécurité, territoire, population. Cours au Collège de France, 1977-78, Paris, Seuil/Gallimard.

Goffman Erving (1961) Asylums: Essays on the Social Situation of Mental Patients and Other Inmates, New York, Ancho Books.

Grojean, Olivier (2008) 'La cause kurde, de la Turquie vers l'Europe. Contribution à une sociologie de la transnationalisation des mobilisations', Paris, Doctoral thesis, EHESS.

Grojean, Olivier (2005) 'Les répertoires du conflit kurde', in Dorronsoro, Gilles (ed.) (2005) La Turquie conteste. Mobilisations sociales et régime sécuritaire, Paris, CNRS Editions, pp. 167-182.

Hersant, Jeanne (2007) 'Mobilisations politiques, co-gouvernementalité et construction ethnique. Sociologie du nationalisme turc à travers le cas des Turcs de Thrace occidentale (Grèce, Allemagne, Turquie)', Paris, Doctoral thesis, EHESS.

Kaufmann, Jean-Claude (2004) L'invention de soi. Une théorie de l'identité, Paris, Armand Colin. 
Labbé, Morgane (2000) La population à l'échelle des frontières. Pour une démographie politique de l'Europe, Paris, Editions de l'EHESS.

Lagroye, Jacques (2002) 'L'institution en pratiques', Revue Suisse de Science Politique, 8(3-4), pp. 114-128.

Lagroye, Jacques (2006) La vérité dans l'Eglise catholique : contestations et restauration d'un régime d'autorité, Paris, Belin.

Lagroye, Jacques; François, Bastien; Sawicki, Frédéric (2002) Sociologie politique, Paris, Presses de Sciences Po et Dalloz.

Lahire, Bernard (1998) L'homme pluriel. Les ressorts de l'action, Paris, Nathan.

Loriga, Sabine (1991) Soldats. Un laboratoire disciplinaire : l'armée piémontaise au XVIII ${ }^{e}$ siècle, Paris, Mentha.

Meeker, Michael (2002) A Nation of Empire. The Ottoman Legacy of Turkish Modernity, Berkeley, University of California Press.

Rigoni, Isabelle (2001) Mobilisations et enjeux des migrations de Turquie en Europe de l'Ouest, Paris, L'Harmattan.

Touraine, Alain (1997) Pourrons-nous vivre ensemble? Égaux et différents, Paris, Fayard.

\section{NOTES}

1. This publication is based on a research seminar on contemporary Turkey held at the Université Paris 1 - Panthéon Sorbonne between 2004 and 2006, and run by Gilles Dorronsoro, Olivier Grojean, and Jeanne Hersant. We wish to thank Benoit Fliche and Noémi Lévy for having read the first version of this text.

2. If we choose to speak of a 'Turkish context' it is because it is not just question of Turkey with its contemporary frontiers and political form. Avoiding temporal and geographic connotations makes it possible to take the Ottoman Empire and Republican Turkey into account, and to include territories annexed to the space of the Turkish nation. Thus the Balkans play a leading role, and not just a symbolical one, in the definition of Turkish nationalism (Hersant 2007). In addition to Western Thrace, considered as within Turkey's zone of influence, these territories include Syria, the Lebanon, and Iraq, where certain political organisations are engaged in conflict with the Turkish State. This definition also makes it possible to include Germany, where largescale immigration has transposed and sometimes recomposed the social divides and political struggles encountered in contemporary Turkey (Amiraux 2001, Rigoni 2001, Grojean 2008).

3. Elsewhere he defines the institution as a 'set of practices, particular tasks, rites and rules of conduct between people', and also as 'the set of beliefs, or representations, relating to these practices, defining their meaning, and tending to justify their existence' (Lagroye, François, \& Sawicki 2002: 227,140).

4. See Fliche (2007) for an overview of theoretical discussions about habitus.

5. The PKK has also sought to carry out surveillance and exert control over Kurdish populations in the regions of Turkey under its control and in Europe (Grojean 2008: 535-545). 